\title{
Narrative Persuasion of Environmental Leaders on Social Media: Case Studies of Two Language Educators
}

Nor Alifah Rosaidi, Razlina Razali, Lew Ya Ling, Ku Azlina Ku Akil, Latisha Asmaak Shafie, Nor Azira Mohd Radzi

To Link this Article: http://dx.doi.org/10.6007/IJARBSS/v12-i1/11688

DOI:10.6007/IJARBSS/v12-i1/11688

Received: 08 November 2021, Revised: 14 December 2021, Accepted: 26 December 2021

Published Online: 15 January 2022

In-Text Citation: (Rosaidi et al., 2022)

To Cite this Article: Rosaidi, N. A., Razali, R., Ling, L. Y., Akil, K. A. K., Shafie, L. A., \& Radzi, N. A. M. (2022). Narrative Persuasion of Environmental Leaders on Social Media: Case Studies of Two Language Educators. International Journal of Academic Research in Business and Social Sciences, 12(1), 612 - 621.

Copyright: (c) 2022 The Author(s)

Published by Human Resource Management Academic Research Society (www.hrmars.com)

This article is published under the Creative Commons Attribution (CC BY 4.0) license. Anyone may reproduce, distribute, translate and create derivative works of this article (for both commercial and non0-commercial purposes), subject to full attribution to the original publication and authors. The full terms of this license may be seen at: http://creativecommons.org/licences/by/4.0/legalcode

Vol. 12, No. 1, 2022, Pg. $612-621$

Full Terms \& Conditions of access and use can be found at http://hrmars.com/index.php/pages/detail/publication-ethics 


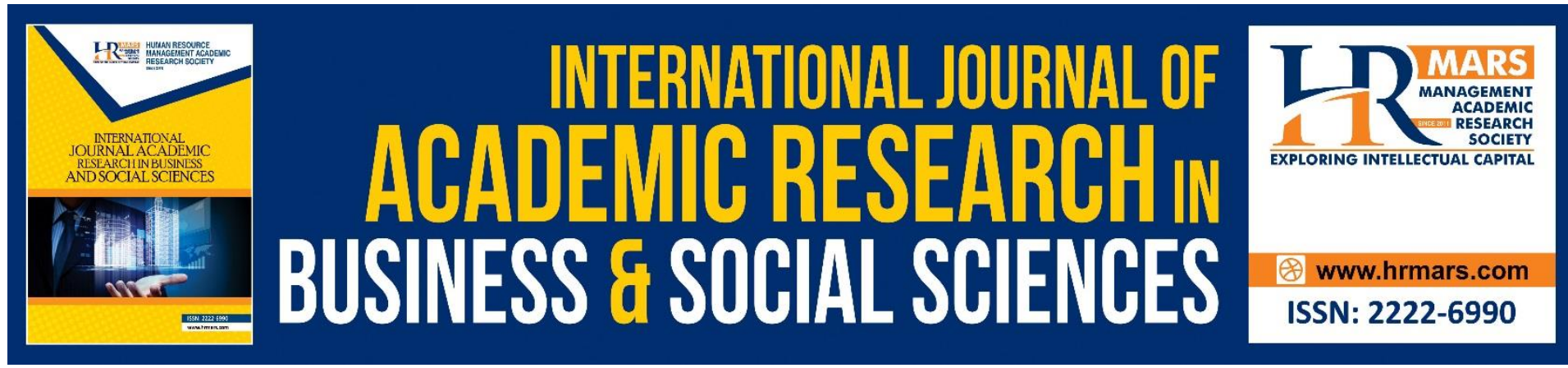

\title{
Narrative Persuasion of Environmental Leaders on Social Media: Case Studies of Two Language Educators
}

\author{
Nor Alifah Rosaidi ${ }^{1}$, Razlina Razali², Lew Ya Ling ${ }^{3}$, Ku Azlina \\ Ku Akil ${ }^{4}$, Latisha Asmaak Shafie ${ }^{5}$, Nor Azira Mohd Radzi ${ }^{6}$ \\ 1, 2,3,5,6 Academy of Language Studies, UiTM Perlis Branch, Perlis, Malaysia, ${ }^{4}$ Faculty of \\ Computer and Mathematical Sciences, UiTM Perlis Branch, Perlis, Malaysia. \\ Email: ${ }^{1} a l i f a h . r o s a i d i @ u i t m . e d u . m y,{ }^{2}$ razlinarazali@uitm.edu.my, ${ }^{4}$ kuazlina@uitm.edu.my, \\ 3yaling@uitm.edu.my, 6norazira202@uitm.edu.my \\ Corresponding Author: ${ }^{5}$ ciklatisha@uitm.edu.my
}

\begin{abstract}
Lack of pro-environmental behaviours from the millennials can be detrimental to current attempts to preserve the environment. However, these millennials do trust their opinion leaders who consist of social influencers. Thus, social influencers play an important role in projecting pro-environmental behaviours and persuading their followers in embracing proenvironmental behaviours. Pro-environmental behaviours can be elicited from the millennials from their opinion leaders. The paper employed a qualitative case study to investigate social influencers' narrative persuasion in eliciting pro-environmental behaviours from their followers. Two social influencers who were language educators participated in the study. These social influencers had more than 1000 followers on their social media accounts. Data were taken from online observation and semi-structured interviews. Data were analysed using thematic analysis. Peer debriefing was used to increase trustworthiness. The findings indicated that these social influencers used narrative transportation, identification and emotions to persuade their followers to exhibit pro-environmental behaviours. Each informant had the environmental issues that they championed and had a deep personal attachment with the issue. They were more concerned with engaging fellow citizens to be more responsible consumers and conserve the environment. They were aware of local and global environmental concerns.
\end{abstract}

Keywords: Environmental Leaders, Language Educators, Narrative Persuasion, ProEnvironmental Behaviours, Social Influencers.

\section{Introduction}

The development of environmental awareness and pro-environmental behaviours are crucial to raise future generations that care for the natural environment in this rapidly changing world. Recently, higher education has played a more active role in environmental education and addressing environmental problems. It has become part of the responsibility for higher education to shape students' and staffs' awareness about the importance of preserving and 
sustaining the natural environment. Among the efforts done to encourage awareness on environmental issues at the university level such as Green Campus and UI GreenMetric World University Ranking. As a center of knowledge and human development, it is argued that higher education should be fully utilized as one of the mediums to disseminate proenvironmental behaviours. Moreover, academics are deemed to be able to comprehend the environmental problems in depth. They are seen as leaders to future generations. Hence, there is a need to identify micro-influencers' narrative persuasion for engaging the public to emulate their pro-environmental behaviours.

With reference to social media, it is recognized as one of the powerful mediums that can be used to disseminate messages about awareness and pro-environmental behaviours especially among millennials. Millennials refers to the group of people who were born between 1980 to 2000 and are digital natives. This generation is also seen as digital natives as they spend a significant amount of time on social media for communication, social connection, entertainment, content creation and sharing as well as to keep themselves updated with current events (Dwivedi \& Lewis, 2020). As a consequence, compared to other generations, millennials are more amenable to ethical issues and are environmentally conscious (Bedard \& Tolmie, 2018). Previous studies suggested that millennial environmental advocators persuade their followers to exhibit pro-environmental behaviours via social media (Hamid et al., 2017). Despite the importance of social media as a channel to spread pro-environmental behaviours, there is still very limited studies conducted in this area (Hamid et al., 2017). Due to that reason, the influence of millennial micro-influencers' environmental leadership on their followers is still not well understood (Bedard \& Tolmie, 2018). To address this gap, this paper investigated narrative persuasion employed by two language educators who were social influencers to persuade pro-environmental behaviors among their followers.

\section{Literature Review}

Scientists communicating environmental issues have become an issue of the past because previous studies have proven that communication about environmental issues is more effective if used with narrative storytelling that can cater to various audiences. However, many studies do not include storytelling when sharing their data (Martinez-Conde et al., 2019). Stories enable complex data to be understood by non-experts which can persuade the public to change and advocate the researchers' missions. Campaigns and communication that use story-based narratives assist the public to understand and advocate environmental issues (Falkheimer \& Heide, 2018). Some governments have begun to use influencer marketing to promote their global image and position themselves as a soft power in the tourism business for example. The term "soft power" in 1980 by Joseph (2021) is to describe a country's ability to persuade or coerce others without resorting to force. In a way, this is a good resort to promote environmental issues among the various audiences.

Narrative Transportation enables the audience to be transported into the stories or realms constructed by the creators (Schank \& Abelson, 1995). Narratives effectively transport the audience to realms constructed by the constructors (Tukachinsky, 2014). Green and Brock (2000) explain that after being transported to the dreams/stories, the travellers are changed by their transportation experiences. During their transportations to the dream worlds, they are not accessible to the origin world. To make the transportation highly effective, the narratives and characters must correlate with the belief and character identification of the participants. 
In narrative persuasion, identification plays an important role as the audience pays attention not to the message but also to the people they relate to. To achieve transportation, the audience needs the entry point to the story. Being social influencers, the audience or followers can influence those who can be transported especially those who have creative minds. De Graaf, Hoeken, Sanders and Beentjes (2012) advocate that when the audience identifies with the actual and fictionalized characters presented in the narrative, they will embrace the beliefs proposed by the characters. The audience may reconstruct their identities to match the characters they like (Green, 2021).

Authenticity allows for the creation of perceived close relationships with followers, which leads to trust, loyalty, and messaging internalization (Kapitan, \& Silvera, 2016). When an influencer can honestly narrate content, they will have no trouble persuading the audience to trust in them. Influencers, particularly those with smaller followings, are seen as more trustworthy by their followers and so better positioned to affect their behaviour, according to political marketers (Goodwin et al., 2020). Each influencer has a distinct brand that attracts a specific segment of their industry's followers. As a brand, knowing your buyer's persona and target demographic is more important than ever, since, with these facts, they can choose the influencer that can best help them to get your message in front of the audiences who matter most to you.

Effective Persuasive strategies often employ the flow of emotions in engaging the audience in their narratives (Nabi \& Gabil, 2015). However, shorter narratives require overall emotional shifts to be relayed by the audience than the characters (Ophir et al., 2021). Previous studies indicate that displaying emotions in environmental communications prevent engagement with the target audience (Bashir et al., 2013; Swim et al., 2018).

The usage of negative emotions in one's expressing concerns on environmental challenges indicates that the individual's caring attitude towards these challenges (Bloodhart et al., 2019; Hornsey et al., 2016). However, using negative emotions is less effective in persuading supporters to advocate environmental petitions. This also shows how social media influencers can legitimate and disseminate bad beliefs, as well as how incentive systems for people who publish this type of content have altered (Goodwin et al., 2020)

Effective leadership among educators consists of having a clear vision, managing people, capacity and developing talent (Leithwood et al., 2020). In addition, Netolicky (2020) highlights the importance of accountability. Christie, Miller, Cooke and White (2015) indicate that educators play important roles as environmental leaders in enhancing their students' environmental awareness and including these issues in their classrooms.

\section{Methodology}

The paper employed a qualitative case study to investigate social influencers' narrative persuasion in eliciting pro-environmental behaviours from their followers. Narrative persuasion theory and social learning theory were used as theoretical frameworks of the study. Two social influencers who were language educators participated in the study. Data were taken from online observation and semi-structured interviews. 
Table 1

Social influencers' demography

\begin{tabular}{|l|l|l|l|l|}
\hline Pseudonym & Gender & Age & Genre & Occupations \\
\hline Maya & Female & 33 & $\begin{array}{l}\text { Beauty } \\
\text { Influencer }\end{array}$ & Language Educator \\
\hline Gaia & Male & 25 & $\begin{array}{l}\text { Lifestyle } \\
\text { Influencer }\end{array}$ & Language Educator \\
\hline
\end{tabular}

Source: online observation and interview sessions

The study used purposive sampling as informants were selected based on their expertise and understanding of the phenomenon studied (Rubin \& Rubin, 2005). The informants were selected based on these criterions:

i. Age between $23-35$ years old

ii. Have $1000-50000$ followers

iii. Show environmental leadership

iv. Teach language

Data were analysed using thematic analysis. Peer debriefing was used to increase trustworthiness of data when one qualitative researcher examined the themes and categorised them.

\section{Findings and Discussion}

The findings indicated that these social influencers used narrative transportation, identification and emotions to persuade their followers to exhibit pro-environmental behaviours. Each informant had the environmental issues that they championed and had a deep personal attachment with the issue. They were more concerned with engaging fellow citizens to be more responsible consumers and conserve the environment. They were aware of local and global environmental concerns.

\section{Theme 1: Narrative Transportation}

Narrative transportation is defined as the concept of being transported into the social influencers' constructed realms that the followers lost grasp of their reality. Both informants used storytelling to transport their followers to their narrative contexts. They put their followers in their world and captivated their followers until these followers lost track of reality. These followers are unable to criticise the contents as they were lost in the realms constructed by the informants. The theme emerged from narrative transportation was demonstrators as illustrated below.

\section{Sub-Theme 1: Demonstrators.}

Demonstrators are defined as experts who shared their expertise by showing followers of how to do something that protect the environment. The informants used narrative transportation by using storytelling elements when demonstrating their practical experiences being sustainable consumers in Extract 1, 2 and 3.

\section{Extract 1:}

By showing them what I do in my social media posting ..sometimes by showing what I bought, what I do and what I wear in my everyday life (Gaia, Interview) 


\section{Extract 2:}

If I want to persuade them, may be I will..like this box..I will inform them let them know this box is made of..it is recycled ..kenapa dia expensive ..it is okay to use..why ...it is recycle box ..okay ..it is not okay to use products yang ada chemical things..if you want to buy things, make sure it is handmade..handmade $\mathrm{ni} \mathrm{mcm}$ use natural ingredients and then how I persuade them..I show the thing and give information ..that is all I can do (Maya, Interview)

\section{Extract 3:}

let say I posted the box on story, this recycled box,,craft box,, there are few and several people yang $\mathrm{dm}$ and said I used the box too...we can recycle and save the environment..if we fold dia lembut, so letak water dia biodegradable..akan ada people yang akan text or dm cakap they use the box too or I have been looking for the box (Maya, Interview)

Self-disclosive strategy was used in the informants' demonstration to persuade their followers to be more environmental conscious. This finding concurs with the study conducted by Norrabiyah et al (2020) claim that social influencers used self-disclosive strategy to persuade their followers to support their causes. In addition, the finding advocates that engagement among social influencers and their followers increased when social influencers used narrative transportation in their posts and videos (Huang et al., 2018; Van Laer et al., 2019).

\section{Theme 2: Identification}

Identification is defined as when the followers identified with social influencers' projected identities and constructed images to invoke support for the social influencers' environmental causes. The social influencers constructed relatable identities with their followers.

\section{Sub- Theme 1: Green Lifestyle Advocators}

Maya and Gaia shown that they were effective persuaders. They were social influencers showed audience-awareness in persuading their followers to implement environmental behaviours as shown in Extract 4, 5 and 6. Both Maya and Gaia believed that their audience wanted green lifestyle advocators who led environmental-friendly lifestyles. Maya realised that her followers consisted of beauty enthusiasts from both genders who appreciated her helpful attitude and realistic beauty tips. She persuaded her audience by promoting products that she used. In Gaia's case, he believed that his audience wanted him to include evidencerich postings of his green lifestyle.

\section{Extract 4}

most of my followers are girls and women..they are also men and boys..so normally when I share my content on Instagram will be on my daily life like what I used ..I do not follow the followers that I have ..I show things that I like and helpful (Maya, Interview)

\section{Extract 5}

People kan nak feel convinced ..mesti dorang nak tahu why ..before you convince people, you need to be convinced, you need to use it first. Let us say , I am selling skincare product, I have to use that first before selling to people (Maya, Interview) 


\section{Extract 6}

sometimes with words doesn't show enough but we need like to do the action and show them without telling them so when they see the actions that we do that contribute to making a safer and greener environment, so they will follow (Gaia, Interview)

This finding support the findings from previous studies suggest that identities shape one's environmental decisions (Kizilay \& Onal, 2019; MgGuire,2015).

\section{Theme 3: Emotion}

Emotion is defined as any texts and images that invoked emotions from the followers to support the social influencers' environmental causes. Social influencers used emotions to persuade their followers to encourage them to exhibit pro-environmental behaviours.

\section{Sub-theme 1: Content Writers.}

Social influencers are concerned about the words being used in their environmental attempts.

\section{Extract 7}

.. Words..texts... and hashtags..the video too (Gaia, Interview)

\section{Extract 8}

Environmental content - I bought the straw made of stainless steel. I bought that one. Once I bought it, I put on my Fb and instagram showing that is actually the best thing to replace the plastic straw because plastic straw is not environmental friendly. Cannot be recycled at all. I have to have that kind of thing first.., use positive environmental related words (Maya, Interview)

\section{Sub-theme 2: Image Constructor}

Social influencers use images to connect with the beliefs of the informants. The informants carefully chosen images that could persuade their followers to support their environmental choices as illustrated by Gaia in Extract 9.

\section{Extract 9}

I am particular with what I post because I don't want people to have negative image of what I do because sometimes when I try to focus on something (environmental issues), they will focus on the background ... I try to choose the content that I share by focussing solely on the content that I want to share (Gaia, Interview)

\section{Extract 10}

Describe and show the picture (related to environmental-friendly products)...before I describe I will find the information, is it good...As for me, recycling ..I don't go and save turtles (Maya, Interview)

Gaia confessed that his followers were influenced by the images he presented in his social media. Therefore, he would carefully choose images that highlighted his messages. His experiences taught him that distractive images would prevent his environmental messages from being received by his followers. Whereas, Maya focused on promoting recycling in her daily life by showing her followers to use recycled products and inculcate recycling as their 
chosen lifestyle preference. The findings support previous studies which emphasised on the connection of messages and images presented (Green, \& Brock, 2002; Leung et al., 2017).

\section{Conclusion}

In the current study, narrative persuasion employed by two language educators who were also social influencers to persuade pro-environmental behaviours among their followers was investigated. Our analysis revealed that narrative transportation, identification and emotions were used by the social influencers in persuading their followers to take on proenvironmental behaviours. Despite the small scale of our study, it has provided valuable insights to other social media influencers especially those among educators about how narrative persuasion can be used to disseminate awareness on pro-environmental issues to their followers. The findings will enable policymaking and activity development that are focused on educating digital natives on pro-environmental behaviours. In addition, findings from the study can be used as a baseline for future studies related to educator leadership in environmental issues.

With the ongoing climate changes and rapid development that disrupt the natural environment, it has become a huge responsibility for higher education to impart knowledge on environmental issues to the current and future generations. To that end, social media plays an important channel to spread awareness and foster pro-environmental behaviours among millennials. Although social media has become part and parcel of our life nowadays, to date there is very limited studies on the role of social media influencers in influencing proenvironmental behaviours to their followers (Hamid et al., 2017) especially among educators. Therefore, future studies should address this gap if we are to create future generation that is not just sensitive about environmental issues but also able to carry out pro-environmental behaviours.

\section{Acknowledgement}

The researchers are grateful for financial fund received from Universiti Teknologi MARA (UiTM) through its internal grant (600-UiTMPs (PJIM\&NPI-DPPD 04). The researchers are thankful to the participants of the research for their participation.

\section{References}

Audrezet, A., De Kerviler, G., \& Moulard, J. G. (2018). Authenticity under threat: When social media influencers need to go beyond self-presentation. Journal of Business Research.

Bashir, N. Y., Lockwood, P., Chasteen, A. L., Nadolny, D., and Noyes, I. (2013). The ironic impact of activists: negative stereotypes reduce social change influence. Eur. J. Soc. Psychol. 43, 614-626. doi: 10.1002/ejsp.1983

Bedard, S. A. N., \& Tolmie, C. R. (2018). Millennials' green consumption behaviour: Exploring the role of social media. Corporate Social Responsibility and Environmental Management, 25(6), 1388-1396. doi:10.1002/csr.1654

Bloodhart, B., Swim, J. K., \& Dicicco, E. (2019). Be Worried, be VERY Worried: Preferences for and Impacts of Negative Emotional Climate Change Communication. Front. Commun. 3(63). doi: 10.3389/fcomm.2018.00063

Christie, B. A., Miller, K. K., Cooke, R., \& White, J. G. (2015). Environmental sustainability in higher education: What do academics think? Environmental Education Research, 21(5), 655 - 686. Retrieved from http://dx.doi.org/10.1080/13504622.2013.879697 
De Graaf, A., Hoeken, H., Sanders, J., \& Beentjes, J. W. (2012). Identification as a mechanism of narrative persuasion. Communication Research, 39(6), 802-823.

Dwivedi, A., \& Lewis, C. (2020). How millennials' life concerns shape social media behaviour. Behaviour \& Information Technology, 1(18). doi:10.1080/0144929x.2020.1760938

Falkheimer, J., \& Heide, M. (2018). Strategic Communication: an introduction (First edition). Routledge

Goodwin, A. M., Joseff, K., \& Woolley, S. C. (2020, October). Social media influencers and the 2020 U.S. election: Paying 'regular people' for digital campaign communication. Center for Media Engagement. https://mediaengagement.org/research/social-mediainfluencers-and-the-2020-election

Green, M. C. (2021). Transportation into Narrative Worlds. In Frank L.B., Falzone P. (Eds.) Entertainment-Education Behind the Scenes. Palgrave Macmillan, Cham. doi.org/10.1007/978-3-030-63614-2_6

Green, M. C., \& Brock, T. C. (2000). The role of transportation in the persuasiveness of public narratives. Journal of Personality and Social Psychology, 79(5), 701-721. doi:10.1037/0022-3514.79.5.701

Hamid, S., ljab, M. T., Sulaiman, H., Anwar, R. M., \& Norman, A. A. (2017). Social media for environmental sustainability awareness in higher education. International Journal of Sustainability in Higher Education. doi:10.1108/ijshe-01-2015-0010

Hornsey, M. J., Harris, E. A., Bain, P. G., and Fielding, K. S. (2016). Meta-analyses of the determinants and outcomes of belief in climate change. Nat. Clim. Chang. 6, 622-626. doi: $10.1038 /$ nclimate2943

Huang, R., Ha, S., and Kim, S. (2018). Narrative persuasion in social media: An empirical study of luxury brand advertising. Journal of Research in Interactive Marketing, 12(3), 274292.

Kızılay, E., \& Onal, N.T. (2019). From the environmental identity to the behavior: The status of pre-service science teachers. International Journal of Evaluation and Research in Education (IJERE), 8(2), 271- 279.

Kapitan, S., \& Silvera, D. H. (2016). From digital media influencers to celebrity endorsers: attributions drive endorser effectiveness. Marketing Letters, 27(3), 553-567.

Leithwood, K., Harris, A., Hopkins, D. (2020). Seven Strong Claims about Successful School Leadership Revisited. School Leadership \& Management, 40 (1): 5-22. doi:10.1080/13632434.2019.1596077.

Leung, M. M., Green, M. C., Tate, D. F., Cai, J., \& Ammerman, A. (2017). Fight for Your Right to Fruit(C: Psychosocial outcomes of a manga comic promoting fruit consumption in middle-school youth. Health Communication, 32(5), 533-540.

Luoma-aho, V., Pirttimäki, T., Maity, D., Munnukka, J., \& Reinikainen, H. (2019). Primed Authenticity: How Priming Impacts Authenticity Perception of Social Media Influencers. International Journal of Strategic Communication, 13(4), 352-365.

Martinez-Conde, S., Alexander, R. G., Blum, D., Britton, N., Lipska, B. K., Quirk, G. J., Macknik, S. L. (2019). The Storytelling Brain: How Neuroscience Stories Help Bridge the Gap between Research and Society. The Journal of Neuroscience: The Official Journal of the Society for Neuroscience, 39(42), 8285-8290. https://doi.org/10.1523/JNEUROSCI.1180-19.2019

McGuire, M. N. (2015). Environmental Education and Behavioral Change: An Identity-Based Environmental Education Model. International Journal of Environmental \& Science Education, 10(5), 695-715. 
Nabi, R. L., \& Green, M. C. (2015). The role of a narrative's emotional flow in promoting persuasive outcomes. Media Psychology, 18(2), 137-162.

Nye, J. S. (2021). Soft Power: The Means to Success in World Politics. 192 pp, Public Affairs, 2004 Foreign Affairs.

Netolicky, D.M. (2020). School leadership during a pandemic: navigating tensions. Journal of Professional Capital and Community, 5( 3/ 4), 391-395. doi.org/10.1108/JPCC-05-20200017

Ophir, Y., Sangalang, A., \& Cappella, J. N. (2021). The emotional flow hypothesis in entertainment-education narratives: Theory, empirical evidence, and open questions. In L. B. Frank \& P. Falzone (Eds.), Entertainment-education behind the scenes: Case studies for theory and practice. Hampshire: Palgrave Macmillan.

Rubin, H. J., \& Rubin, I. S. (2005). Qualitative Interviewing: The Art of Hearing Data (2nd ed.). Thousand Oaks, CA: Sage.

Swim, J. K., Geiger, N., Sweetland, J., \& Fraser, J. (2018). Social construction of scientifically grounded climate change discussions. In S. Clayton and C. Manning (Eds.), Psychology and Climate Change (pp 65- 93). London: Elsevier. doi: 10.1016/B978-0-12-8131305.00004-7

Schank, R. C., \& Abelson, R. P. (1995). Knowledge and memory: The real story. In R. S. Wyer, Jr. (Ed.), Knowledge and memory: The real story (pp. 1-85). Lawrence Erlbaum Associates, Inc.

Scott, M. (2018). An analysis of how social media influencers utilise trust-building strategies to create advocates. Journal of Promotional Communications, 6(2).

Tukachinsky, R. (2014). Experimental manipulation of psychological involvement with media. Communication Methods and Measures, 8(1), 1-33.

Van Laer, T., Feiereisen, S., and Visconti, L. M. (2019). Storytelling in the Digital Era: Relevant Moderators of the Narrative Transportation Effect. Journal of Business Research, 96, 135-146. doi: 10.1016/j.jbusres.2018.10.053 